Jurnal Kejuruteraan 30(2) 2018: 123-128

http://dx.doi.org/10.17576/jkukm-2018-30(2)

\title{
Generation of Artificial Road Profile for Automobile Spring Durability Analysis
}

\author{
(Penjanaan Profil Jalan Pembuatan bagi Analisis Kebolehtahanan Pegas Gegelung Kereta) \\ Kong Yat Sheng \\ Centre for Integrated Design of Advanced Mechanical System (PRISMA), \\ Faculty of Engineering \& Built Environment, Universiti Kebangsaan Malaysia, Bangi, Malaysia \\ Faculty of Engineering, University of Duisburg-Essen, Duisburg, Germany \\ Shahrum Abdullah* \& Sallehuddin Mohamed Haris \\ Centre for Integrated Design of Advanced Mechanical System (PRISMA), \\ Faculty of Engineering \& Built Environment, Universiti Kebangsaan Malaysia, Bangi, Malaysia \\ Mohd Zaidi Omar \\ Centre for Engineering Materials and Smart Manufacturing (MERCU), \\ Faculty of Engineering \& Built Environment, Universiti Kebangsaan Malaysia, Bangi, Malaysia \\ Dieter Schramm \\ Faculty of Engineering, University of Duisburg-Essen, Duisburg, Germany
}

\begin{abstract}
This paper presents the use of a generated artificial road profile in the simulation of a quarter car model for spring durability based-force extraction. In situ measurement of the road loading profile for automotive spring durability analysis, requires considerable cost and effort due to the complex experimental setup. Hence, an artificial road profile was generated for the quarter car model simulation to obtain the spring force signals. Initially, according to the ISO 8608 standard, a class "A" artificial road profile was generated using a designated waviness value, unevenness index and random phase angle. The generated road profile was used as the input to a constructed quarter car model to obtain the spring force signals. Subsequently, the generated nominal force signal was used to predict the fatigue life of the spring. Moreover, to obtain the localise fatigue behaviour of the spring, a finite element spring model together with the force signal was used for fatigue prediction. Under this class " A" road excitation, the spring possessed very high fatigue life of $1.87 \times 10^{6}$ blocks to failure. Further, a series of spring variant was analysed for fatigue life through this road class excitation. The relationship between spring stiffness and fatigue lives established using power regression and the coefficient of determination $\left(R^{2}\right)$ as high as 0.9815 was obtained. Therefore, this analysis will assist in automobile spring design regarding fatigue when road load data is not available.
\end{abstract}

Keywords: Artificial road profile; quarter car model; strain life approach; fatigue life

ABSTRAK

Kertas kerja ini membentangkan penggunaan profil jalan pembuatan untuk simulasi model kereta suku bagi penjanaan beban kebolehtahanan pegas gegelung. Pengukuran profil jalan sebenar merupakan salah satu bahagian daripada analisis kebolehtahanan pegas gegelung yang mermerlukan kos dan kerja yang banyak kerana penyediaan eksperimen adalah rumit. Satu profil jalan pembuatan telah dijana untuk simulasi kereta suku bagi mendapatkan signal beban pegas gegelung. Berdasarkan standard ISO 8608, satu kelas "A" profil pembuatan telah dijana dengan menggunakan nilai kegelombangan, indeks ketaksamaan dan sudut fasa yang rawak. Profil jalan yang dijana telah digunakan sebagai input kepada sebuah model kereta suku untuk mendapatkan signal beban pegas. Seterusnya, beban nominal yang dijana tersebut digunakan untuk meramal hayat lesu pegas tersebut. Untuk mendapatkan sifat lesu setempat bagi pegas, satu model unsur terhingga pegas dengan signal beban telah digunakan untuk peramalan hayat lesu. Dengan pengaruh jalan kelas " A" tersebut, pegas telah mempunyai satu hayat lesu yang tinggi sebanyak $1.87 \times 10^{6}$ kitaran. Satu siri pegas yang berlainan telah dianalisis untuk hayat lesu dengan menggunakan kelas jalan tersebut. Perkaitan antara ketegangan dan hayat lesu telah dibina dengan menggunakan regresi power dan pekali penentuan setinggi 0.9815 telah didapati. Analisis ini membantu reka bentuk pegas otomobil dari segi kelesuan tanpa menggunakan profil jalan yang diukur

Kata kunci: Profil jalan pembuatan; model kereta suku; kaedah hayat terikan; hayat lesu 


\section{INTRODUCTION}

Road pavement induces detrimental effects on the passenger car, such as a reduction in passengers' comfort and increment of stress on vehicle's components. Nevertheless, the process to obtain an actual road profile measurement is not simple and yet costly (Lin et al. 2013). Since the road data measurements were not always available, a method to classify road profiles was proposed by ISO 8608 . The benefit of using this artificial road profile is the capability to have full control over their geometric properties (e.g. roughness level, full length) which affecting the phenomenon. When compared to on road measurement data, artificial road profiles consist also lesser noise or unwanted features (ISO 8608, 2016). Moreover, it is also possible to quickly generate road profiles with the different roughness which belong to different road class.

Seeing the benefits of using the artificial road profiles, the number of published research works regarding artificial road profile has extensively increased throughout the year. For example, Agostinacchio et al. (2014) utilized the artificial road profiles to evaluate the effects of road surface degradation due to the vehicle speed and types. However, the main reason to apply the generated artificial road profiles was to simulate the actual road profile. This means that the generated profile should bear resemblance to the measured road profile. In the automotive industry, one of the ambitions is to have a minimum number of physical prototyping (Ogunoiki \& Olatunbosun 2015). The measurement of road load data should be as minimum as possible when durability assessment of a new vehicle is conducted.

Nowadays, enhancement in regression approaches has assisted relationship modelling of automotive component fatigue. For example, Kong et al. (2017) utilized the power law regression method to model spring fatigue life and vehicle vertical vibration. Putra et al. (2017) applied wavelet and Fuzzy C-Means technique to edit strain signals of coil spring to shorten the signal length. For bias modelling, Zhao et al. (2016) proposed an approach to reduce discrete variables so that the accuracy of the model could be improved. Their proposed coil spring deformation has shown an improved accuracy when compared to traditional bias modelling method. Based on this literature, the trends have shown that automotive coil spring design was assisted by different established regression models.

In this paper, a power law regression-based model for spring fatigue life was established using an artificially generated road profile. The process to evaluate the fatigue behavior of a spring under road excitation is important but costly because the measurements include experimental setup and numerous prototype samples. Meanwhile, during the experimental measurement, lots of human efforts are also needed because the spring prototype was changed after a sufficiently long data collection process. The process of changing a spring includes removing of the tyres and dissembles the suspension of the vehicle. Therefore, to minimize the unnecessary works, the fatigue assessment of spring using an artificial road profile which closes to the actual profile is important. Based on the literature review, there is no such mathematical formulation has been proposed. This generated relationship was used to reduce the coil spring design period.

\section{METHODOLOGY}

A total of eight classes of road roughness were proposed by ISO 8608 which was from class A to H. For simulations, the ISO 8608 provided that the road roughness profiles PSD were defined using Equation 1 (ISO 8608 2016):

$$
G_{d}(n)=G_{d}\left(n_{o}\right) \cdot\left(\frac{n}{n_{o}}\right)^{-2}
$$

where $G_{d}\left(n_{o}\right)$ is the degree of roughness value, $n_{o}$ is the spatial frequency, $n$ is the number of road length data point. In this case, the geometric mean values of the road roughness profile were used to formulate the road profile. To generate the artificial road profile, the geometric value of the PSD was used. The road profile was regarded as a simple harmonic function, as shown in Equation 2 (Agostinacchio et al. 2014):

$$
h(x)=A_{i} \cos \left(2 \pi \cdot n_{i} \cdot x+\varphi\right)
$$

where $h(x)$ is the amplitude of the vertical displacement, $A_{i}$ is the amplitude which obtained from the mean square value of the component for the spatial frequency, is the phase angle, $n_{i}$ is the

After the road profile was generated, quarter car model was constructed to perform the simulation for spring force time history extraction. The schematic diagram of a constructed quarter car simulation model is shown in Figure 1. This quarter car model consisted of a spring and damper linear element which defined the translation movement of the sprung mass in the vertical direction. The spring stiffness was $19 \mathrm{~N} / \mathrm{mm}$ while the damping coefficient was $16 \mathrm{~N} . \mathrm{s} /$ mm (Putra et al. 2015). The coil spring and damper were connected to a wheel element via a ball joint. The wheel element is a linear elastic element where a stiffness value of $0.1 \mathrm{~N} / \mathrm{m}$ was defined (Soltani et al. 2015). A connecting rod was also modelled to ensure the correct mechanism of the suspension system. A tyre patch was modelled under the wheel component. In this analysis, the generated artificial road loadings were defined at this tyre patch.

Then, the coil spring of the vehicle was analyzed using finite element method (FEM). Initially, the CAD model of the spring was pre-processed using three-dimensional (3D) tetrahedral solid elements. A total of 9227 nodes and 7170 elements were defined in this model. The $3 \mathrm{D}$ tetrahedral meshed coil spring model is shown in Figure 2. A rigid body was created at the top of the spring while another rigid body was applied at the bottom of the spring. A translational force of $3000 \mathrm{~N}$ was applied from the bottom of the spring. The vehicle weight was assumed to be distributed evenly among four wheels and the vehicle weight was $1200 \mathrm{~kg}$ when fully loaded with passengers. Hence, a static force of $3000 \mathrm{~N}$ was 
applied from the top of the spring to simulate the spring under loaded conditions. Subsequently, the stress-strain state of the coil spring was obtained.
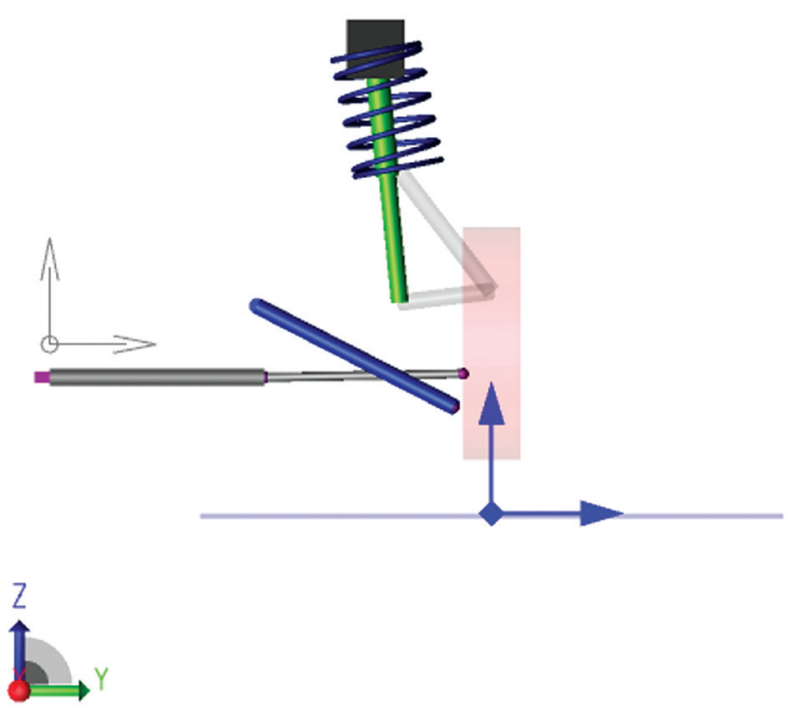

FIGURE 1. Schematic diagram of quarter car model

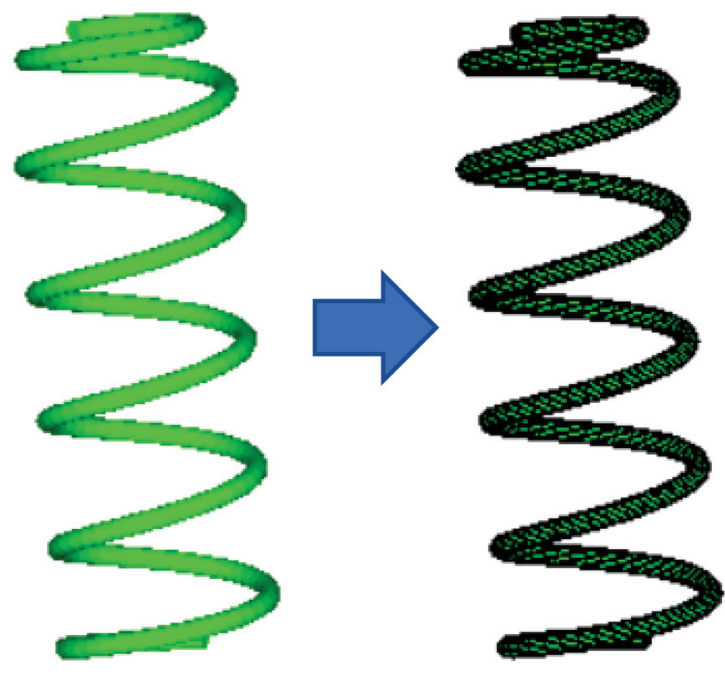

FIGURE 2. 3D Tetrahedral meshed spring model

Spring sensitivity analysis was performed to analyze the effects of varying spring stiffness towards the loading condition. In this case, the spring design was changed according to the formula as shown in Equation 3 (Gandomi 2015):

$$
k=\frac{G d^{4}}{8 N D^{3}}
$$

where $k$ is the spring stiffness, $G$ is the material shear modulus, $N$ is the number of the active coils, $d$ is the spring material bar size, $D$ is the mean diameter of spring. Changing the mean coil diameter and number of the active coil of the spring requires reconsideration of suspension working space. To achieve different spring stiffness without much affecting the suspension working space, the most ideal way was to adjust the material bar diameter. After that, fatigue life of each newly designed springs was obtained using strain-life fatigue approaches. Strain-life fatigue approaches were selected instead of stress-life because the spring was considered failed when a crack was initiated. Smith-Watson-Topper (SWT) strain life model was selected because of its applicability for steel applications. The SWT strain life model could be defined as in Equation 4 (Abdullah et al. 2008):

$$
\begin{aligned}
\sigma_{\max } \varepsilon_{a} E= & \left(\sigma_{f}^{\prime}\right)^{2}\left(2 N_{f}\right)^{b} \\
& +\sigma_{f}^{\prime} \varepsilon_{f}^{\prime} E\left(2 N_{f}\right)^{b+c}
\end{aligned}
$$

$\sigma_{f}^{\prime}$ is the fatigue strength coefficient, $N_{f}$ is the number of cycles to failure for a particular stress range, is the fatigue strength exponent, $\varepsilon_{f}^{\prime}$ is the fatigue ductility coefficient, and is the fatigue ductility exponent.

\section{RESULTS AND DISCUSSIONS}

The preliminary result of this research is the artificially generated road profile according to ISO 8608 standard. The generated class "A" artificial road profile is shown in Figure 3. This road profile consisted of 8000 data points and a total length of $100 \mathrm{~s}$. For statistical analysis, the mean value of this generated road profile is $0.47 \times 10^{-6} \mathrm{~m}$ while the root mean square value (r.m.s) is $0.0046 \mathrm{~m}$. Proposed $\mathrm{m}$ ean and r.m.s value of ISO 8608 class A road was $0.16 \times 10^{-6}$ and 0.0040 $\mathrm{m}$, respectively. When compared to the ISO 8608 standard, the difference was very small. The difference was existing because the amplitude was generated according to random number as well as phase angle. In terms of energy content, power spectral density (PSD) of the artificial road class " $A$ " was obtained and shown in Figure 4. As observed in Figure 4 , the energy contents decayed over the frequency range. This indicating that the energy content of higher frequency was lower when compared to the lower frequency range. Besides that, it was also indicating that the road excitation was at low frequency which was around $0.1 \mathrm{~Hz}$.

The suspension component design shall avoid this particular frequency range to avoid resonance which caused extra deformations. The frequency of automobile sprung mass was from 1.4 to $4 \mathrm{~Hz}$ for vertical motion. However, the frequency range for automobile suspension was usually 6 to 10 greater than the sprung mass which is approximately to be $10 \mathrm{~Hz}$ (Agostinacchio et al. 2014). Through using this generated road profile as input to quarter car simulation, force time history of the current spring stiffness was obtained. For the nominal spring design, the extracted force time history from quarter car model simulation was extracted and shown in Figure 5. The range of the force loading signal was between -200 to $200 \mathrm{~N}$. When compared to the static load, this amplitude range was not high because the smooth road surface did not provide huge excitations.

One of the significant analysis prior to fatigue life prediction was FEA stress-strain analysis. After a static simulation, FEM stress distribution of the coil spring was 


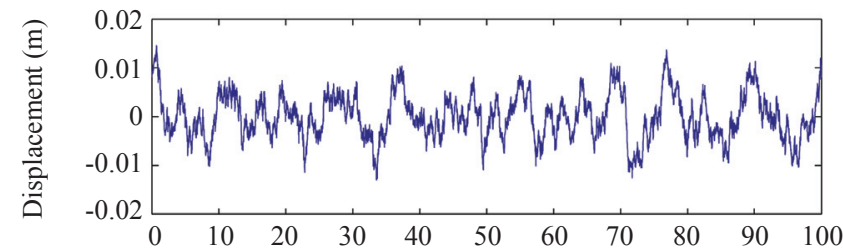

FIGURE 3. Generated artificial road profile class "A"

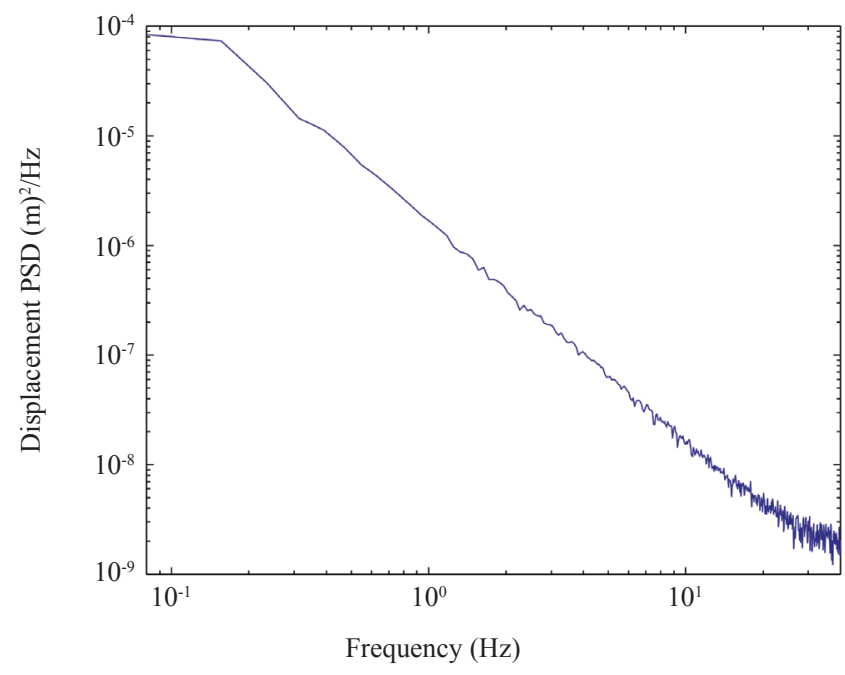

FIGURE 4. PSD of road profile class "A"

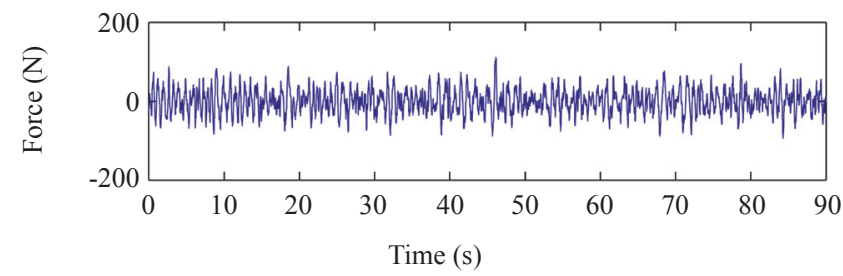

FIGURE 5. Extracted force time history from simulation

analyzed. This analysis was important because the fatigue failure area was related to the stress where the crack initiation occurred at the peak stress region (Meneghetti et al. 2014). A proper finite modelled spring possessed details of the geometry captured with discretized fine elements. After the static analysis was performed, the von Mises stress distribution of the spring is provided in color stress contours as shown in Figure 6. The region with the highest stress level is shown in red while the lowest stress region is shown in blue. As observed from Figure 6, the highest stress region was distributed at the inner surface of the spring. Same high stress region was also reported by Del Llano-Vizcaya et al. (2006). Although coil spring is a simple component when the torsional loading was exerted, the stress states of the spring were becoming complicated.

After the FEA stress-strain analysis was obtained, the information and data were used to predict the spring fatigue life using SWT strain life model. With the stress-strain FEA results, the fatigue life distribution of the original coil spring design was obtained as shown in Figure 7. Red contour indicated the region with the lowest fatigue life while the
Contour Plot

Element Stresses

Analysis system
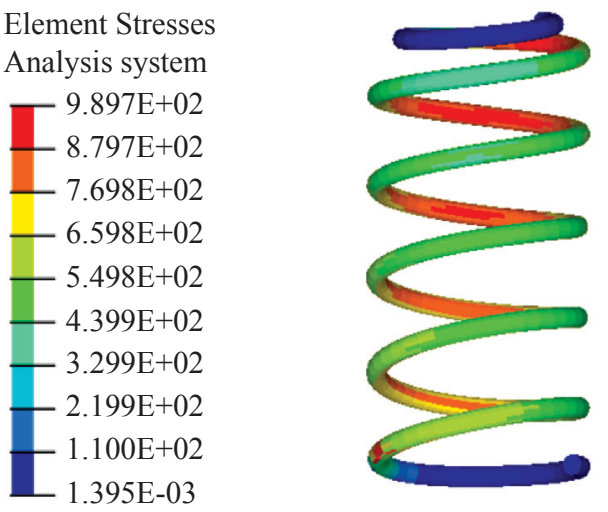

FIGURE 6. FEM stress distribution of nominal spring

blue contour is shown the high fatigue life regime. The region of spring with low fatigue life was the same as the region of high- stress concentration in uniaxial loading because the stress level has direct effects on the fatigue life. The obtained minimum fatigue life of the spring was $1.87 \times 10^{6}$ blocks to failure which located the highest stress point of FEM results. Mahmud et al. (2015) performed a fatigue analysis on coil spring and obtained estimated fatigue life of $2.00 \times 10^{6}$ blocks to failure. The proposed fatigue life was very close to this analysis results.

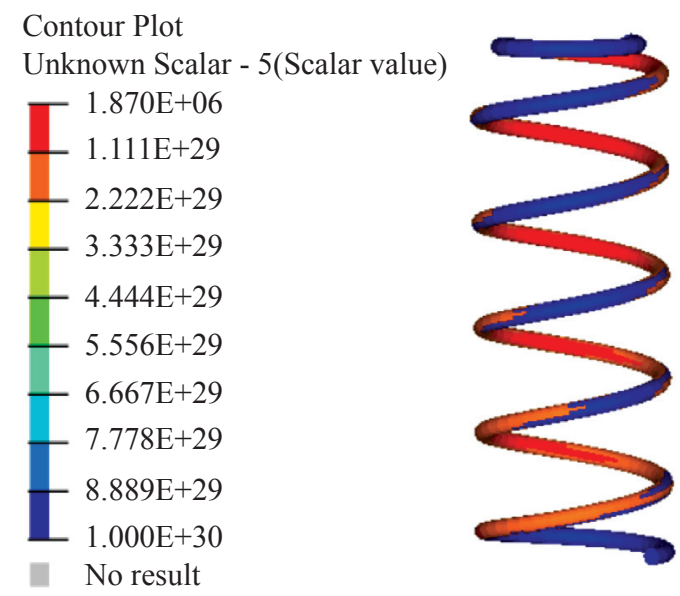

FIGURE 7. Fatigue life contour of nominal spring

The critical analysis of this research was the effects of different spring design towards its fatigue life. The results of spring stiffness towards its bar diameter are tabulated in Table 1. As observed from Table 1, increasing the bar diameter lead to the increment of spring stiffness. Meanwhile, spring stiffness is inversely proportional to its fatigue lives. This was because the spring stiffness was directly proportional to the loadings that exerted on the spring itself. When the spring stiffness was higher, the loading was higher and hence, reduced the fatigue life of the spring. Although the bar size has been increased, the different bar size tends to reduce the stress level, but the effects are minor when compared to the influence of loadings. 
The relationship between spring stiffness and fatigue lives was plotted using power law regression. The fitted curve of spring stiffness and fatigue lives using power law is shown in Figure 8. The power law is a nonlinear regression which suitable for data that increasing at a specific rate which was suitable for material fatigue applications (Maya-Johnson et al. 2015). The spring stiffness was plotted against spring fatigue lives and a function was obtained as follows Equation 5:

$$
k=93.56 N^{0.1033}
$$

where $k$ is the spring stiffness and $N$ is the corresponding fatigue life. Base on the curve fitting, a coefficient of determination value $\left(R^{2}\right)$ as high as 0.9830 was obtained.

Based on the obtained $R^{2}$ value, it proposed that there was a strong correlation between spring fatigue lives and stiffness under a power relationship. As proposed by Sivák \& Ostertagová (2012), a $R^{2}$ value above 0.90 was considered as very good while a $R^{2}$ value above 0.80 was good. Sometimes application with a $R^{2}$ value above 0.60 was also considered as acceptable. Through this power law modelling, fatigue life of the coil spring could be estimated under a fixed road excitation with varying loadings. The obtained mean square error for this regression-based durability model was 0.8741 . The MSE was considered low when compared to the spring stiffness value. Nevertheless, there are a few limitations that induced in this model. This power regression model was suitable only for prediction under road class " $A$ " because the predicted fatigue life was based on this generated artificial road class. Stochastic road profiles yielded some very different statistical properties which could lead to different results. Meanwhile, this power regression-based fatigue life model utilized SWT strain life model for fatigue life prediction. Hence, the obtained fatigue life was only based on SWT model because SWT is suitable for steel applications (Abdullah et al. 2008). However, this analysis served to assist automotive coil spring design to shorten the design process through reducing the number of prototypes.

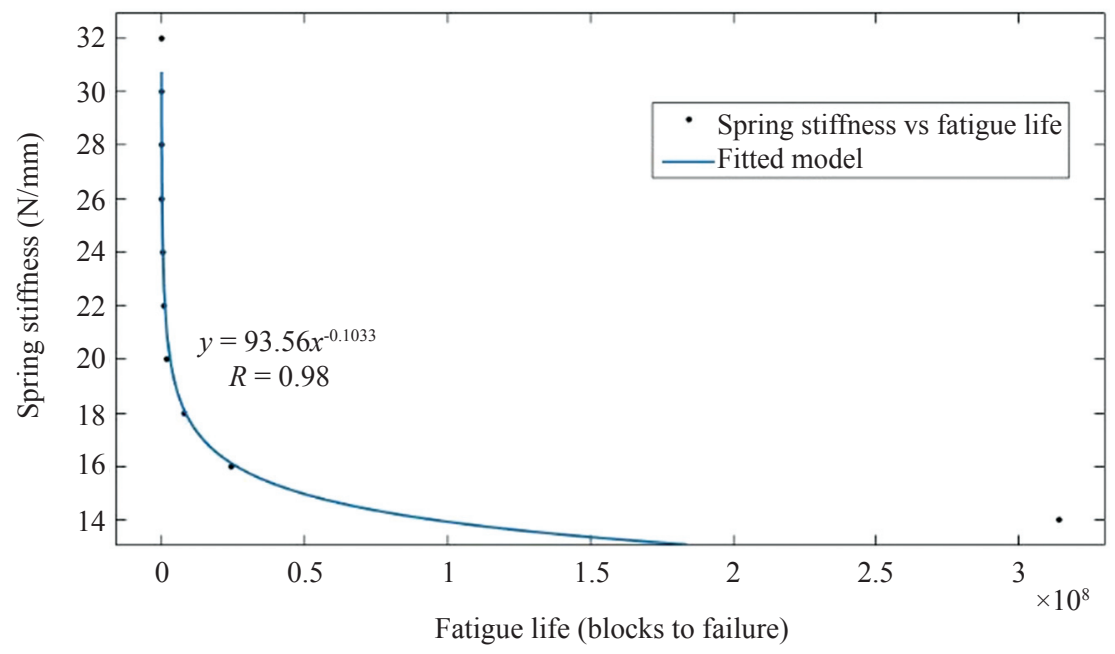

FIGURE 8. Fitted curve of fatigue life

TABLE 1. Spring sensitivity parameters and fatigue lives

\begin{tabular}{ccc}
\hline $\begin{array}{c}\text { Spring design } \\
\text { (stiffness, N/mm) }\end{array}$ & $\begin{array}{c}\text { Bar diameter, } \\
d(\mathrm{~mm})\end{array}$ & $\begin{array}{c}\text { Fatigue life } \\
\text { (blocks to failure) }\end{array}$ \\
\hline$k 14(14)$ & 11.0 & $3.14 \times 10^{8}$ \\
$k 16(16)$ & 11.3 & $2.44 \times 10^{7}$ \\
$k 18(18)$ & 11.6 & $8.20 \times 10^{6}$ \\
$k 20(20)$ & 12.0 & $1.87 \times 10^{6}$ \\
$k 22(22)$ & 12.2 & $9.35 \times 10^{5}$ \\
$k 24(24)$ & 12.4 & $4.42 \times 10^{5}$ \\
$k 26(26)$ & 12.6 & $2.34 \times 10^{5}$ \\
$k 28(28)$ & 12.8 & $1.00 \times 10^{5}$ \\
$k 30(30)$ & 13.0 & $6.45 \times 10^{4}$ \\
$k 32(32)$ & 13.3 & $4.78 \times 10^{4}$ \\
\hline
\end{tabular}

In this analysis, there were a few limitations like the road class " $A$ " was used to simulate the spring fatigue life. In actual condition, the road class " $\mathrm{B}$ " and " $\mathrm{C}$ " could deal higher fatigue damage than class "A." However, this research aimed to analyse the trend of fatigue life according to spring design. Meanwhile, the assumptions that all components of the vehicle were in an ideal condition where the components were fully functioning.

\section{CONCLUSION}

The relationship between spring stiffness and fatigue lives was successfully established using a power law regression. From the power law regression, a $R^{2}$ value as high as 0.8320 was obtained which indicate the strong correlation between spring stiffness and fatigue life. The obtained MSE was 0.8741 and it was relatively low when compared to spring stiffness value. The generated power law regression-based fatigue life model assists the coil spring design with targeted fatigue life as input. This model reduced the numbers of required spring prototype during automotive suspension design process. 
REFERENCES

Abdullah, S., Choi, J.C., Yates, J.R. \& Giacomin, J.A. 2008 Use of strain-life models with wavelet bump extraction algorithm (WBE) for predicting fatigue damage. Jurnal Kejuruteraan 20: 33-44.

Agostinacchio, M., Ciampa, D. \& Olita, S. 2014. The vibrations induced by surface irregularities in road pavements - a Matlab ${ }^{\circledR}$ approach. European Transport Research Review 6(3): 267-275.

Del Llano-Vizcaya, L., Rubio-González, C., Mesmacque, G. \& Cervantes-Hernández, T. 2014. Multiaxial fatigue and failure analysis of helical compression springs. Engineering Failure Analysis 13(8): 1303-1313.

Gandomi, A.H. 2015. Structural optimization using interior search algorithm. Iranian Journal of Structural Engineering 2(1): 19-27.

ISO 8608, 2016. Mechanical Vibration, road surface profiles. International Standardization Organization, Geneva, Switzerland.

Kong, Y.S., Abdullah, S., Schramm, D., Omar, M.Z. \& Haris, S.M. 2017. The significance to establish a durability model for an automotive ride. SAE Technical Paper, 2017-01-0347.

Lin, G., Pang, H., Zhang, W., Wang, D., Feng, L., Lin, G., Pang, H., Zhang, W., Wang, D. \& Feng, L. 2013. A self-decoupled three-axis force sensor for measuring the wheel force. Proceedings of the Mechanical Engineering, Part D: Journal of Automobile Engineering 228(3): 319-334.

Mahmud, M., Abdullah, S., Ariffin, A.K., Nopiah, M.Z., Yunoh, M.F.M. \& Mansor, N.I.I. 2015. Determining the behaviour of fatigue strain histories of vehicle coil springs by using statistical inferences. Applied Mechanics and Materials 786: 409-414.

Maya-Johnson, S., Ramirez, A.J. \& Toro, A. 2015. Fatigue crack growth of two pearlitic rail steels. Engineering Fracture Mechanics 138: 63-72.

Meneghetti, G., Guzzella, C. \& Atzori, B. 2014. The peak stress method combined with 3D finite element models for fatigue assessment of toe and root cracking in steel welded joints subjected to axial or bending loading. Fatigue and Fracture of Engineering Materials \& Structures 37(7): 722-739.

Ogunoiki, A. \& Olatunbosun, O. 2015. Artificial road load generation using artificial neural network. SAE Technical Paper 2015-01-0639.

Putra, T.E., Abdullah, S., Schramm, D., Nuawi, M.Z. \& Bruckmann, T. 2017. Reducing cyclic testing time for components of automotive suspension system utilizing the wavelet transform and the Fuzzy C-Means. Mechanical Systems and Signal Processing 90: 1-14.
Putra, T.E., Abdullah, S., Schramm, D., Nuawi, M.Z. \& Bruckmann, T. 2015. Generating strain signals under consideration of road surface profiles. Mechanical Systems and Signal Processing 60: 485-497.

Sivák, P. \& Ostertagová, E. 2012. Evaluation of Fatigue Tests by Means of Mathematical Statistics. Procedia Engineering 48: 636-642.

Soltani, A., Goodarzi, A., Shojaeefard, M.H. \& Saeedi, K 2015. Optimising tire vertical stiffness based on ride, handling, performance, and fuel consumption criteria. Journal of Dynamic Systems, Measurement and Control 137(12): 121004.

Zhao, X., Xi, Z., Xu, H. \& Yang, R.J. 2016. Model bias characterization considering discrete and continuous design variable. Proceedings of the ASME 2016 International Design Engineering and Technical Conferences and Computers and Information in Engineering Conference, August, North California.

\section{Kong Yat Sheng}

*Shahrum Abdullah

Sallehuddin Mohamed Haris

Centre for Integrated Design of Advanced Mechanical System (PRISMA),

Faculty of Engineering \& Built Environment

Universiti Kebangsaan Malaysia

43600 UKM Bangi, Malaysia.

Mohd Zaidi Omar

Centre for Engineering Materials and Smart Manufacturing (MERCU),

Faculty of Engineering \& Built Environment

Universiti Kebangsaan Malaysia

43600 UKM Bangi, Malaysia.

Dieter Schramm

Faculty of Engineering,

University of Duisburg-Essen,

47057 Duisburg, Germany.

*Corresponding author; email: shahrum@ukm.edu.my

Received date: $20^{\text {th }}$ April 2018

Accepted date: $14^{\text {th }}$ July 2018

Online First date: $1^{\text {st }}$ September 2018

Published date: $31^{\text {st }}$ October 2018 